\title{
Impact of gene polymorphisms on toxicity and response rate in head and neck squamous cell carcinoma: a literature review
}

hamid abbaszadeh ( $\sim$ hamidabbaszade@yahoo.com )

Birjand University of Medical Sciences https://orcid.org/0000-0002-7443-0607

Mahdieh Rajabi-Moghaddam

Birjand University of Medical Sciences

\section{Research Article}

Keywords: Gene polymorphism, Single nucleotide polymorphisms, Head and neck squamous cell carcinoma, Treatment outcome, Toxicity

Posted Date: January 11th, 2022

DOI: https://doi.org/10.21203/rs.3.rs-1217709/v1

License: (c) (i) This work is licensed under a Creative Commons Attribution 4.0 International License. Read Full License 


\section{Abstract}

Advanced head and neck squamous cell carcinoma (HNSCC) is treated with radiotherapy, chemotherapy, targeted therapy or a combination of these treatments. Variations in toxicity and response to therapy are observed among patients despite similar clinicopathologic characteristics which are attributed to single nucleotide polymorphisms (SNPs). The aim of this review was to evaluate the impact of SNPs on toxicity and response to therapy in HNSCCs. A web-based search of all original articles about the impact of gene polymorphisms on toxicity and response to therapy in HNSCCs was done until September 2021 using international English language databases including Google Scholar, Scopus, PubMed and Web of science. Findings were categorized by type of treatment (radiotherapy, chemotherapy, targeted therapy, or combination therapy). In each category, studies related to growth control genes, cell proliferation, apoptosis, DNA repair genes, antioxidant and drug detoxification genes, genes of drug metabolizing enzymes, tissue remodeling genes and genes of antibodydependent cellular cytotoxicity were discussed separately. Among studied SNPs with probable impact on toxicity and response to therapy are XRCC1, XRCC3, RAD51, Ku70, NBN, CAT, GSTP1, GSTT1, GSTM1, XPD, XPC, ERCC1, MMP3, ACSL6, EX01, CXP2D6, FcyRIlla, AurkA, and EGFR. Understanding gene polymorphisms will help us move toward personalized medicine and determine which patients will actually benefit from therapies for HNSCCs. By examining the SNPs, it is possible to make predictions about the patient's response to treatment or development of toxicity after treatment, and if necessary, make changes in the patient's treatment regimen.

\section{Introduction}

Head and neck squamous cell carcinomas (HNSCCs) are the seventh most common cancer in the world; 5 -year survival rate is around $25-60 \%$ (Fakhry et al. 2008, Ansell et al. 2009).

Treatment of HNSCCs includes one of the surgery, radiotherapy or chemotherapy treatments or a combination of these treatments. Concurrent chemoradiotherapy is still the mainstay of HNSCCs treatment, especially in unresectable ones, which has been associated with variable individual clinical outcomes despite similar clinical-pathological features (Nogueira et al. 2018, Blons et al. 2004). One problem with cancers, especially HNSCCs, is the unpredictability of treatment outcomes, both in terms of tumor response and host toxicity. Some cases have been associated with resistance to radiotherapy or chemotherapy and local recurrence. Identifying molecular markers that are effective in responding to treatment is important in order to optimize therapies (Ansell et al. 2009, Shukla et al 2012).

Various factors are effective in the local control of the tumor and the response to therapy. It has been suggested that radiation sensitivity and chemosensitivity of cancer cells may play an important role in the local control of the tumor following these therapies. Individual genetic variations lead to different responses of patients to a single treatment regimen. Therefore, knowing the genetic variations (polymorphisms) will be effective in predicting the response to treatment, and accordingly, we can determine which patients will benefit from chemo- or radiotherapy (Ansell et al. 2009).

On the other hands, researches have been conducted to find molecular markers for predicting the development of treatmentinduced acute or chronic toxicity before initiation of treatment (Venkatesh et al. 2014).

So, the aim of this review was to investigate the effect of single nucleotide polymorphisms (SNPs) on response rate and toxicity in HNSCCs.

\section{Materials And Methods}

A comprehensive search was conducted to find potentially relevant articles in the following English (international) databases: PubMed, Scopus, Web of Science and Google Scholar.

The search was performed based on the following keywords in the mentioned databases, using Boolean operators (OR, AND): 
"Oral cavity", "Mouth", "larynx", "nasopharynx", "hypopharynx", "oropharynx", "pharynx", " head and neck", "squamous cell carcinoma", "tumor", "neoplasm", "cancer", "malignancy", "gene", "polymorphism ", "gene polymorphism", "single nucleotide polymorphism", "SNP ", "response", "treatment ", "therapy", "treatment outcome", "treatment effectiveness", "drug resistance", "toxicity", "radiotherapy", "chemotherapy", "molecular targeted therapy".

The search was conducted from August 2021 to September 2021; all original research-related articles conducted until September 2021 were included in the study and retrieved, and EndNote X7 software was used to manage the studies.

Inclusion criteria included the following: studies evaluating squamous cell carcinoma of the head and neck area; crosssectional and case-control studies; articles in English language; all original research articles; studies which reported impact of gene polymorphism (SNP) on treatment response; studies which included tumor response or head and neck cell line response; studies which reported impact of gene polymorphism (SNP) on toxicity of normal tissues; studies which included radiotherapy, chemotherapy, targeted therapy, or combination of these as treatment method.

Exclusion criteria were as follows: studies evaluating neoplasms located in other parts of the body other than head and neck area; studies evaluating neoplasms other than squamous cell carcinoma; articles written in languages other than English; case report articles, reviews and letters to the editor articles; studies which did not report the impact of gene polymorphism (SNPs) on treatment response; studies which did not report the impact of gene polymorphism on toxicity of normal tissue; studies which included the impact of gene or protein expression on treatment response; studies which included the impact of gene or protein expression on toxicity; studies which reported the impact of gene polymorphism (SNPs) on prognosis; studies which reported the impact of gene polymorphism (SNPs) on survival (overall survival, progression-free survival, disease-free survival, disease-specific survival, mortality); studies which reported the impact of gene polymorphism (SNPs) on recurrence of tumor; studies which reported the impact of gene polymorphism (SNPs) on cancer risk or susceptibility.

\section{Results}

A total of 25 studies related to the objectives of this review article were found, and a summary of the characteristics of these studies is given in Table 1 (Table 1). 
Table 1

Characteristics of the included studies in this review

\begin{tabular}{|c|c|c|c|c|c|}
\hline $\begin{array}{l}\text { First author, } \\
\text { year }\end{array}$ & $\begin{array}{l}\text { Studied Genes } \\
\text { (polymorphisms) }\end{array}$ & $\begin{array}{l}\text { Gene } \\
\text { category }\end{array}$ & Type of treatment & Primary tumor site & $\begin{array}{l}\text { Number } \\
\text { of } \\
\text { cases }\end{array}$ \\
\hline Blons, 2004 & $\begin{array}{l}\text { MMP-1 (1607insG), } \\
\text { MMP-3 (1612insA), MMP- } \\
7 \text { (181A3G, 153C3T) }\end{array}$ & $\begin{array}{l}\text { Tissue } \\
\text { remodeling } \\
\text { gene }\end{array}$ & $\begin{array}{l}\text { Neoadjuvant } \\
\text { Chemotherapy } \\
\text { (cisplatin, 5- } \\
\text { fluorouracil }\end{array}$ & $\begin{array}{l}\text { Oral cavity, } \\
\text { oropharynx, } \\
\text { hypopharynx, } \\
\text { larynx }\end{array}$ & 148 \\
\hline Kimura, 2004 & GSTP1(I105V) & $\begin{array}{l}\text { Antioxidant } \\
\text { and drug } \\
\text { detoxification } \\
\text { genes }\end{array}$ & $\begin{array}{l}\text { Chemotherapy } \\
\text { (cisplatin) }\end{array}$ & HNSCC Cell lines & 17 \\
\hline $\begin{array}{l}\text { Quintela- } \\
\text { Fandino, } \\
2006\end{array}$ & $\begin{array}{l}\text { XPD (Asp312Asn, } \\
\text { Lys751GIn), ERCC1 } \\
\text { (C8092A), XRCC1 } \\
\text { (Arg399GIn) }\end{array}$ & $\begin{array}{l}\text { DNA-repair } \\
\text { gene }\end{array}$ & $\begin{array}{l}\text { Induction } \\
\text { chemotherapy } \\
\text { (cisplatin) }\end{array}$ & $\begin{array}{l}\text { Nasopharynx, oral } \\
\text { cavity, oropharynx, } \\
\text { hypopharynx, } \\
\text { larynx, lip }\end{array}$ & 103 \\
\hline \multirow[t]{2}{*}{ Alsbeih, 2008} & XRCC1( & \multirow{2}{*}{$\begin{array}{l}\text { DNA-repair } \\
\text { gene }\end{array}$} & \multirow[t]{2}{*}{ Radiotherapy } & \multirow[t]{2}{*}{ Nasopharynx } & \multirow[t]{2}{*}{50} \\
\hline & $\begin{array}{l}399 \text { G > A Arg/GIn), XRCC3 } \\
\text { (241 C> T Thr/Met) }\end{array}$ & & & & \\
\hline \multirow[t]{2}{*}{$\begin{array}{l}\text { Werbrouck, } \\
2009\end{array}$} & $\begin{array}{l}\text { XRCC3 }(c .-1843 A>G, \\
\text { c. } 562-14 A>G, c .722 C>T), \\
\text { Rad51 }(c .-3429 \mathrm{G}>C, \\
\text { c. }-3392 G>T), \text { Lig4 } \\
\text { (c. } 26 C>T,\end{array}$ & \multirow[t]{2}{*}{$\begin{array}{l}\text { DNA-repair } \\
\text { gene }\end{array}$} & \multirow[t]{2}{*}{$\begin{array}{l}\text { Radiotherapy, } \\
\text { chemoradiotherapy, } \\
\text { radiotherapy + surgery, } \\
\text { chemoradiotherapy + } \\
\text { surgery }\end{array}$} & \multirow[t]{2}{*}{$\begin{array}{l}\text { Oral cavity, } \\
\text { oropharynx, } \\
\text { hypopharynx, } \\
\text { larynx, neck }\end{array}$} & \multirow[t]{2}{*}{88} \\
\hline & $\begin{array}{l}\text { c. } 1704 \mathrm{~T}>\mathrm{C}), \mathrm{Ku} 70 \\
(\mathrm{c} .-1310 \mathrm{C}>\mathrm{G}), \text { and Ku80 } \\
(\mathrm{c} .2110-2408 \mathrm{G}>\mathrm{A})\end{array}$ & & & & \\
\hline Ansell, 2009 & FGFR4 (Gly/Arg) & $\begin{array}{l}\text { Growth } \\
\text { control }\end{array}$ & $\begin{array}{l}\text { Radiation and } \\
\text { cisplatin }\end{array}$ & HNSCC Cell lines & 39 \\
\hline $\begin{array}{l}\text { Farnebo, } \\
2009\end{array}$ & 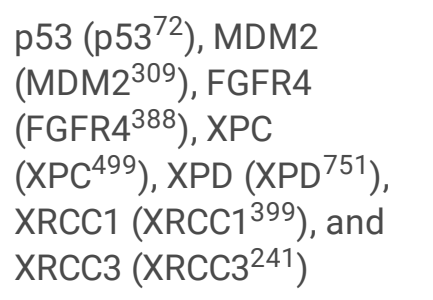 & $\begin{array}{l}\text { Apoptosis, } \\
\text { Growth } \\
\text { control, DNA- } \\
\text { repair gene }\end{array}$ & $\begin{array}{l}\text { Chemotherapy } \\
\text { (cisplatin) }\end{array}$ & HNSCC Cell lines & 39 \\
\hline Taylor, 2009 & FcyRIIla & $\begin{array}{l}\text { Antibody- } \\
\text { dependent } \\
\text { cellular } \\
\text { cytotoxicity }\end{array}$ & $\begin{array}{l}\text { Targeted therapy } \\
\text { (Cetuximab[anti- } \\
\text { EGFR]) }\end{array}$ & HNSCC Cell lines & 3 \\
\hline $\begin{array}{l}\text { Klinghammer, } \\
2010\end{array}$ & $\begin{array}{l}\text { EGFR (EGFR-R521Kand } \\
\text { CA-SSR) }\end{array}$ & $\begin{array}{l}\text { Growth } \\
\text { control }\end{array}$ & $\begin{array}{l}\text { Targeted therapy } \\
\text { +Chemotherapy } \\
\text { (cetuximab/docetaxel) }\end{array}$ & $\begin{array}{l}\text { recurrent or } \\
\text { metastatic HNSCC }\end{array}$ & 51 \\
\hline \multirow[t]{3}{*}{ Pratesi, 2011} & $\begin{array}{l}\text { XRCC1 (c.1196A > G), } \\
\text { XRCC3 }\end{array}$ & $\begin{array}{l}\text { DNA-Repair } \\
\text { Gene }\end{array}$ & $\begin{array}{l}\text { chemo-radiotherapy } \\
\text { and }\end{array}$ & \multirow{3}{*}{$\begin{array}{l}\text { nasopharynx, } \\
\text { oropharynx, oral } \\
\text { cavity, } \\
\text { hypopharynx }\end{array}$} & \multirow[t]{3}{*}{101} \\
\hline & $\begin{array}{l}(c .722 C>T), \text { RAD51 } \\
\text { c. }-3429 G>C, c .-3392 G> \\
\text { T) }\end{array}$ & \multirow[t]{2}{*}{$\begin{array}{l}\text { Antioxidant } \\
\text { and drug } \\
\text { detoxification } \\
\text { genes }\end{array}$} & \multirow[t]{2}{*}{ radiotherapy alone } & & \\
\hline & GSTP1 (c.313A > G) & & & & \\
\hline
\end{tabular}




\begin{tabular}{|c|c|c|c|c|c|}
\hline $\begin{array}{l}\text { First author, } \\
\text { year }\end{array}$ & $\begin{array}{l}\text { Studied Genes } \\
\text { (polymorphisms) }\end{array}$ & $\begin{array}{l}\text { Gene } \\
\text { category }\end{array}$ & Type of treatment & Primary tumor site & $\begin{array}{l}\text { Number } \\
\text { of } \\
\text { cases }\end{array}$ \\
\hline Ruwali,2011 & $\begin{array}{l}\text { GSTM1(null/positive), } \\
\text { GSTT1(null/positive), } \\
\text { GSTP1(Ile/Val) }\end{array}$ & $\begin{array}{l}\text { Antioxidant } \\
\text { and drug } \\
\text { detoxification } \\
\text { genes }\end{array}$ & $\begin{array}{l}\text { Chemotherapy, } \\
\text { chemoradiotherapy }\end{array}$ & $\begin{array}{l}\text { oral cavity, larynx, } \\
\text { pharynx }\end{array}$ & 500 \\
\hline Ziliak, 2011 & $\begin{array}{l}\text { ACSL6 (rs6870861, } \\
\text { rs2551038) }\end{array}$ & $\begin{array}{l}\text { Fatty acid } \\
\text { biosynthesis }\end{array}$ & $\begin{array}{l}\text { Induction } \\
\text { chemotherapy } \\
\text { (carboplatin-based) }\end{array}$ & $\begin{array}{l}\text { Head and neck } \\
\text { cancers }\end{array}$ & 60 \\
\hline Shukla, 2012 & CYP2D6 & $\begin{array}{l}\text { Drug- } \\
\text { metabolizing } \\
\text { enzymes }\end{array}$ & $\begin{array}{l}\text { Cisplatin-based } \\
\text { Chemoradiotherapy }\end{array}$ & $\begin{array}{l}\text { oral cavity, } \\
\text { oropharynx, the } \\
\text { hypopharynx, and } \\
\text { the larynx }\end{array}$ & 100 \\
\hline $\begin{array}{l}\text { Venkatesh, } \\
2014\end{array}$ & $\begin{array}{l}\text { XRCC1 (rs25487, } \\
\text { rs1799782, rs25489, } \\
\text { rs3213245), XRCC3 } \\
\text { (rs861539), XRCC4 } \\
\text { (rs1805377), XRCC5 or } \\
\text { Ku80 (rs3835), XRCC6 or } \\
\text { Ku70 (rs2267437), LIG4 } \\
\text { (rs1805388), } \\
\text { NBN (rs1805794, } \\
\text { rs1805787), RAD51 } \\
\text { (rs1801320, rs1801321), } \\
\text { ATM (rs3218698), OGG1 } \\
\text { (rs1052133), TGF31 } \\
\text { (rs1800469), CAT } \\
\text { (rs7943316), SOD2 } \\
\text { (rs4880), } \\
\text { NQ01(rs1131341),GSTP1 } \\
\text { (rs1695), GSTT1) } \\
\text { (Present/Null), GSTM1 } \\
\text { (Present/Null) }\end{array}$ & $\begin{array}{l}\text { DNA damage } \\
\text { and repair } \\
\text { genes, } \\
\text { Profibrotic } \\
\text { and } \\
\text { inflammatory } \\
\text { cytokine, } \\
\text { Antioxidant } \\
\text { and drug } \\
\text { detoxification } \\
\text { genes }\end{array}$ & $\begin{array}{l}\text { Platinum based } \\
\text { chemoradiotherapy or } \\
\text { radiotherapy alone }\end{array}$ & $\begin{array}{l}\text { Hypopharynx, } \\
\text { Oropharynx, } \\
\text { Nasopharynx, } \\
\text { Larynx, } \\
\text { Oral cavity, } \\
\text { Para nasal region, } \\
\text { Parotid }\end{array}$ & 183 \\
\hline $\begin{array}{l}\text { Pickhard, } \\
2014\end{array}$ & $\begin{array}{l}\text { Aurora kinase A } \\
\text { (AurkA/STK15 Phe31lle) }\end{array}$ & $\begin{array}{l}\text { Cell } \\
\text { proliferation }\end{array}$ & $\begin{array}{l}\text { Targeted therapy } \\
\text { (cetuximab) }\end{array}$ & Cell lines & 6 \\
\hline $\begin{array}{l}\text { Pfisterer, } \\
2015\end{array}$ & $\begin{array}{l}\text { AKT1 (rs2494738, } \\
\text { rs2498804, rs3803304), } \\
\text { AKT2 (rs892119, } \\
\text { rs8100018), FRAP1 } \\
\text { (rs11121704, rs2295080), } \\
\text { PIK3CA (rs2699887, } \\
\text { rs7640662), and PTEN } \\
\text { (rs12569998, rs2299939) }\end{array}$ & $\begin{array}{l}\text { Cell } \\
\text { proliferation }\end{array}$ & $\begin{array}{l}\text { Targeted therapy } \\
+ \text { Chemotherapy } \\
\text { (cetuximab-docetaxel) }\end{array}$ & $\begin{array}{l}\text { Recurrent or } \\
\text { initially metastatic } \\
\text { HNSCC (oral cavity, } \\
\text { oropharynx, the } \\
\text { hypopharynx) }\end{array}$ & 45 \\
\hline $\begin{array}{l}\text { Danielsson, } \\
2015\end{array}$ & $\begin{array}{l}\text { OGG1 (rs1052133), } \\
\text { MTH1/NUDT1 (rs4866), } \\
\text { CAT (rs1001179), SOD2A } \\
\text { (rs4880), NOS3 } \\
\text { (rs1799983), GSTP1 } \\
\text { (rs1695), GSTA1 } \\
\text { (rs3957356), NFE2L2 } \\
\text { (rs1806649) }\end{array}$ & $\begin{array}{l}\text { Antioxidant } \\
\text { and drug } \\
\text { detoxification } \\
\text { genes }\end{array}$ & $\begin{array}{l}\text { Radiotherapy alone, } \\
\text { radiotherapy }+ \\
\text { brachytherapy, } \\
\text { radiotherapy }+ \\
\text { chemotherapy }\end{array}$ & $\begin{array}{l}\text { HNSCC with } \\
\text { osteoradionecrosis( } \\
\text { Tonsil, Tongue, } \\
\text { other) }\end{array}$ & 37 \\
\hline \multirow[t]{2}{*}{$\begin{array}{l}\text { Fernández- } \\
\text { Mateos, } 2016\end{array}$} & $\begin{array}{l}\text { EGFR } \\
\text { (rs2227983,rs28384375, } \\
\text { rs17336639), CCDN1, } \\
\text { FCGR2A (rs1801274), }\end{array}$ & $\begin{array}{l}\text { Growth } \\
\text { control }\end{array}$ & $\begin{array}{l}\text { chemotherapy and } \\
\text { radiotherapy plus } \\
\text { cetuximab (targeted } \\
\text { therapy) }\end{array}$ & $\begin{array}{l}\text { Larynx, } \\
\text { Oropharynx, } \\
\text { Hypopharynx, Oral } \\
\text { cavity }\end{array}$ & 110 \\
\hline & $\begin{array}{l}\text { FCGR3A (rs396991), } \\
\text { KRAS-LCS6 (rs61764370) }\end{array}$ & & & & \\
\hline
\end{tabular}




\begin{tabular}{|c|c|c|c|c|c|}
\hline $\begin{array}{l}\text { First author, } \\
\text { year }\end{array}$ & $\begin{array}{l}\text { Studied Genes } \\
\text { (polymorphisms) }\end{array}$ & $\begin{array}{l}\text { Gene } \\
\text { category }\end{array}$ & Type of treatment & Primary tumor site & $\begin{array}{l}\text { Number } \\
\text { of } \\
\text { cases }\end{array}$ \\
\hline Braig, 2017 & EGFR $\left(E G F R-K_{521}\right)$ & $\begin{array}{l}\text { Growth } \\
\text { control }\end{array}$ & $\begin{array}{l}\text { cetuximab (targeted } \\
\text { therapy) }\end{array}$ & HNSCC Cell lines & 14 \\
\hline $\begin{array}{l}\text { Lopes-Aguiar, } \\
2017\end{array}$ & $\begin{array}{l}\text { XPC }(c .2815 A>C), X P D \\
(c .934 G>A), X P D \\
(c .2251 A>C), \text { XPF } \\
(c .2505 T>C), E R C C 1 \\
(c .354 C>T)\end{array}$ & $\begin{array}{l}\text { DNA-repair } \\
\text { gene }\end{array}$ & $\begin{array}{l}\text { Cisplatin-based } \\
\text { chemoradiotherapy }\end{array}$ & $\begin{array}{l}\text { Oral cavity, } \\
\text { Pharynx, Larynx }\end{array}$ & 90 \\
\hline $\begin{array}{l}\text { Baumann, } \\
2018\end{array}$ & $\begin{array}{l}\text { Aurora-Kinase A (Phe31- } \\
\text { Ile) }\end{array}$ & $\begin{array}{l}\text { Cell } \\
\text { proliferation }\end{array}$ & $\begin{array}{l}\text { radiation + Docetaxel } \\
\text { (chemotherapeutic } \\
\text { agent) + Aurora- } \\
\text { Kinase inhibitor } \\
\text { (targeted therapy) }\end{array}$ & HNSCC cell lines & 2 \\
\hline Nanda, 2018 & XRCC-1 (Arg194Trp) & $\begin{array}{l}\text { DNA-repair } \\
\text { gene }\end{array}$ & $\begin{array}{l}\text { Concurrent } \\
\text { chemoradiotherapy }\end{array}$ & $\begin{array}{l}\text { oral cavity, } \\
\text { hypopharynx, } \\
\text { oropharynx, larynx }\end{array}$ & 101 \\
\hline $\begin{array}{l}\text { Nogueira, } \\
2018\end{array}$ & $\begin{array}{l}\text { MLH1 } \\
\text { (c.-93G>A; rs1800734), } \\
\text { MSH2 (c.211+9C>G; } \\
\text { rs2303426), MSH3 } \\
\text { (c.3133G>A; rs26279), } \\
\text { EXO1 (c.1765G>A; } \\
\text { rs1047840), EXO1 } \\
\text { (c.2270C>T; rs9350), }\end{array}$ & $\begin{array}{l}\text { DNA-repair } \\
\text { gene }\end{array}$ & $\begin{array}{l}\text { Chemotherapy } \\
\text { (cisplatin)+ } \\
\text { radiotherapy }\end{array}$ & $\begin{array}{l}\text { oral cavity, } \\
\text { pharynx, larynx }\end{array}$ & 90 \\
\hline Wang, 2020 & $\begin{array}{l}\text { ERCC1 (rs11615, } \\
\text { rs3212948, rs3212961, } \\
\text { rs735482) }\end{array}$ & $\begin{array}{l}\text { DNA-repair } \\
\text { gene }\end{array}$ & Chemotherapy & oral cavity & 113 \\
\hline Tejasvi, 2020 & $\begin{array}{l}\text { ERCC1 (rs11615, } \\
\text { rs3212986) }\end{array}$ & $\begin{array}{l}\text { DNA-repair } \\
\text { gene }\end{array}$ & $\begin{array}{l}\text { Chemotherapy } \\
\text { (cisplatin) }\end{array}$ & oral cavity & 150 \\
\hline
\end{tabular}

\section{Impact of gene polymorphisms on toxicity and response to radiotherapy}

\subsection{Response to radiotherapy}

\subsubsection{Growth control genes}

\subsubsection{Fibroblast growth factor}

FGFR4 Gly/Arg polymorphism association with radiation resistance has been studied. The results showed that no association between $\mathrm{Arg}^{388}$ allele and radiosensitivity (Ansell et al. 2009).

\subsection{Toxicity post radiotherapy}

\subsubsection{DNA repair genes}

\subsubsection{Base excision repair pathway}

In a study to explore the association of DNA-repair gene polymorphism with late complication to radiotherapy (fibrosis) in nasopharyngeal carcinoma patients, there was significant association between XRCC1 399 G/A polymorphism and grade of 
fibrosis post radiotherapy; XRCC1 399 A (Gln) allele was significantly lower in radiosensitive patients (with higher grade of fibrosis). There was no significant association between XRCC3 $241 \mathrm{C}>\mathrm{T}$ polymorphism and grade of fibrosis (Alsbeih et al. 2008).

In a study to investigate the role of gene polymorphisms in radiosensitivity (acute reactions), there was a significant association between XRCC1-399GIn allele and mucositis in head and neck cancer patients treated with radiotherapy alone. XRCC1-399GIn allele was not significantly associated with skin toxicity (erythema) (Pratesi et al. 2011).

In a study to explore the effect of polymorphisms in radio-responsive genes on acute toxicity among head and neck cancer patients, none of the studied polymorphisms of DNA-damage and repair genes (XRCC1 and OGG1) had significant relationship with severe skin reactions post radiotherapy (Venkatesh et al. 2014).

\subsubsection{Homologous recombination repair pathway}

In Pratesi et al. study, there was a significant association between RAD51 c.-3429 CC/GC genotypes and higher grade of dysphagia in patients treated with radiotherapy alone. The risk of acute toxicities was significantly higher in patients with at least one SNP or the co-occurrence of both SNPs in XRCC1 p.Gln399Arg /RAD51 c.-3429 G > C (Pratesi et al. 2011).

In a study to investigate effect of gene polymorphisms on normal tissue reactions to radiotherapy in head and neck cancer patients, XRCC3 c.722CT/TT polymorphism had a significant association with occurrence of severe dysphagia. There were not any associations between XRCC3 (c.-1843A>G, c.562-14A>G, c.722C>T) and Rad51 (c.-3429G>C, c.-3392G>T)

polymorphisms and occurrence of mucositis or dermatitis after radiotherapy (Werbrouck et al. 2009).

In Venkatesh et al. study, none of the studied polymorphisms of DNA-damage and repair genes (XRCC3, RAD51 and ATM) had significant relationship with severe skin reactions post radiotherapy (Venkatesh et al. 2014).

\subsubsection{Nonhomologous end-joining repair pathway}

In Werbrouck et al. study, Ku70 (XRCC6) c.-1310CG/GG polymorphism had a significant association with occurrence of severe dysphagia. There were not any associations between Lig4 (c.26C>T, c.1704T>C), Ku70 (c. $-1310 \mathrm{C}>\mathrm{G}$ ), and Ku80 (c.2110-2408G>A) polymorphisms and occurrence of mucositis or dermatitis after radiotherapy (Werbrouck et al. 2009).

In Venkatesh et al. study, none of the studied polymorphisms of DNA-damage and repair genes (XRCC4, XRCC5, XRCC6 and LIG4) had significant relationship with severe skin reactions post radiotherapy (Venkatesh et al. 2014).

\subsubsection{Double strand DNA break repair pathway}

In Venkatesh et al. study, NBN variants introduced as predictive tools for occurrence of sever oral mucositis after radiotherapy. Recessive allele of NBN gene (rs1805794) was significantly associated with severe oral mucositis. None of the studied polymorphisms of NBN DNA repair gene (rs1805794, rs1805787) had significant relationship with severe skin reactions post radiotherapy (Venkatesh et al. 2014).

\subsubsection{Antioxidant and drug detoxification genes}

In Venkatesh et al. study, heterozygous variant of CAT gene (rs7943316) was significantly associated with lower grades of oral mucositis post radiotherapy (Venkatesh et al. 2014).

There was no significant relationship between glutathione s-transferase P1 (GSTP1) c.313 A > G polymorphism and acute toxicities (mucositis, erythema and dysphagia) post radiotherapy (Pratesi et al. 2011).

In a study to assess the effect of eight gene polymorphisms on osteoradionecrosis (ORN) post radiation therapy of head and neck cancers, rs1695 SNP in GSTP1 gene was more frequent in patients with ORN (Danielsson D et al. 2016). 


\section{Impact of gene polymorphisms on toxicity and response to chemotherapy}

\subsection{Response to chemotherapy \\ 2.1.1. DNA repair genes}

\subsubsection{Base excision repair pathway}

In a study to investigate the effect of DNA repair gene polymorphisms on clinical outcome of HNSCC patients treated with cisplatin-based induction chemotherapy, SNP of human X-ray repair cross-complementing gene 1 (XRCC1-Arg399GIn) was significantly associated with response to treatment; XRCC1-399 GIn/GIn genotype was associated with increased possibility of complete response to treatment. The conclusion was that this SNP may act as response to cisplatin predictor (QuintelaFandino et al. 2006).

In a study on HNSCC cell lines, XRCC1 SNP $\left(\mathrm{XRCC}^{399}\right)$ increased cisplatin sensitivity but this increase was not significant (Farnebo L et al. 2009).

\subsubsection{Nucleotide excision repair pathway}

In Quintela-Fandino et al. study on HNSCC patients, SNPs of xeroderma pigmentosum complementation group D (XPDAsp312Asn, XPD-Lys751GIn) and excision repair cross complementary gene 1 (ERCC1-C8092A) were associated with response to treatment (cisplatin-based induction chemotherapy); among them the association of XPD-Asp312Asn was significant and this association was borderline for ERCC1-C8092A SNP; XPD-312Asn/Asn genotype was associated with increased possibility of complete response to treatment. Also, with accumulation of each additional polymorphic variant, the possibility of complete response to treatment significantly increased. They proposed that these SNPs may act as response to cisplatin predictors (Quintela-Fandino et al. 2006).

In Farnebo et al. study on HNSCC cell lines, SNPs in XPC and XPD increased cisplatin sensitivity but these increases were not significant (Farnebo et al. 2009).

In a study to assess the effect of gene polymorphisms of ERCC1 on treatment response of patients with oral squamous cell carcinoma, four studied ERCC1 SNPs (rs11615, rs3212948, rs3212961, and rs735482) were not associated with response to chemotherapy (Wang et al. 2020).

In a study to assess the effect of ERCC1 gene polymorphisms on response to cisplatin-based chemotherapy in oral SCC patients, ERCC1 $118 \mathrm{C} / \mathrm{T}$ and C8092A SNPs had significant impact on treatment response; patients who carry ERCC1 rs11615 (C118T) CC and CT genotypes had good response to treatment in comparison with TT genotypes; patients who carry ERCC1 rs3212986 (C8092A) CC and CA genotypes had good response to treatment in comparison with AA genotypes (Tejasvi et al. 2020).

\subsubsection{Homologous recombination repair pathway}

In Farnebo et al. study on HNSCC cell lines, XRCC3 SNP increased cisplatin sensitivity but this increase was not significant. The result in this study showed that XRCC ${ }^{241}$ and $X^{2} D^{751}$ SNPs together with expression of epidermal growth factor receptor (EGFR), Hsp70, Bax, and Bcl-2 proteins increased cisplatin sensitivity and can be a predictive marker of cisplatin sensitivity of HNSCC cell lines (Farnebo et al. 2009).

\subsubsection{Antioxidant and drug detoxification genes}


Glutathione S-transferase P1 (GSTP1) polymorphism (I105V) has been studied in head and neck squamous cell carcinoma (HNSCC) cell lines treated with cisplatin. Presence of heterozygous genotype for this polymorphic gene was associated with a better response to cisplatin treatment. It has been proposed that GSTPI $1105 \mathrm{~V}$ polymorphism may be used as a predictive marker for drug resistance (Kimura et al. 2004).

\subsubsection{Growth control}

FGFR4 Gly/Arg polymorphism association with chemoresistance has been studied. The results showed increase in cisplatin sensitivity in Arg $^{388}$ allele of polymorphic gene but this relationship was not significant (Ansell et al. 2009).

In a study on HNSCC cell lines, FGFR4 ${ }^{388}$ SNPs increased cisplatin sensitivity but this increase was not significant. The result in this study showed that FGFR4388 SNPs together with expression of EGFR, Hsp70, Bax, and Bcl-2 proteins increased cisplatin sensitivity (Farnebo et al. 2009).

\subsubsection{Cell proliferation}

In a study to assess the effect of PI3K/PTEN/AKT/mTOR polymorphisms on treatment response of head and neck cancer patients receiving cisplatin- or platinum-based chemotherapy agents, there was no association between these polymorphisms and treatment response (Pfisterer et al. 2015).

\subsubsection{Apoptosis}

In a study on HNSCC cell lines, $\mathrm{p} 53^{72}$ and $\mathrm{MDM}^{309}$ SNPs did not affect cisplatin sensitivity. The result in this study showed that $\mathrm{p} 53^{72}$ and $M D M 2^{309}$ SNPs together with expression of EGFR, Hsp70, Bax, and Bcl-2 proteins increased cisplatin sensitivity (Farnebo et al. 2009).

\subsubsection{Connective tissue remodeling genes}

The role of Matrix metalloproteinases (MMPs) in response to chemotherapy through interaction with the Fas/ Fas ligand pathway has been proposed. MMP3-1612insA has been associated with neoadjuvant chemotherapy response as an independent chemosensitivity factor; HNSCC with $6 \mathrm{~A} / 6 \mathrm{~A}$ genotype responded better to neoadjuvant chemotherapy than $5 \mathrm{~A} / 6 \mathrm{~A}$ or $5 \mathrm{~A} / 5 \mathrm{~A}$ genotypes (Blons $\mathrm{H}$ et al. 2004).

\subsubsection{Fatty acid biosynthesis}

Two SNPs of Long-chain acyl-CoA synthetase 6 (ACSL6) gene including rs6870861 and rs2551038 had significant association with response to induction chemotherapy (carboplatin) (Ziliak et al. 2011).

\section{Impact of gene polymorphisms on toxicity and response to chemoradiotherapy}

\subsection{Response to chemoradiotherapy}

\subsubsection{DNA repair genes}

\subsubsection{Base excision repair pathway}

In a study to explore the relation of XRCC-1Arg194Trp polymorphism with response to treatment in HNSCC patients achieving chemoradiotherapy, although complete response rates in patients with polymorphic variant was better than wild type variant, the difference was not significant (Nanda et al. 2018).

\subsubsection{Nucleotide excision repair pathway}


In a study to explore the effect of DNA-repair gene polymorphisms on outcome of HNSCCs treated with cisplatin-based chemoradiotherapy, patients with XPD c.934AA genotype and AA haplotype of XPD had significantly more chance to experience complete response post chemoradiotherapy (Lopes-Aguiar et al. 2017).

\subsubsection{Mismatch repair (MMR) pathway}

In a study to investigates effect of mismatch repair (MMR) pathway gene polymorphisms on response to cisplatin-based chemoradiotherapy in HNSCC patients, patients with EXO1 rs1047840 GG genotype were significantly associated with complete response to treatment;

Patients with AC haplotype of EX01 rs1047840 and rs9350 SNPs had more chance to experience partial response or stable disease after treatment compared to patients with other EXO1 haplotypes which experience higher chance for complete response (Nogueira et al. 2018).

\subsubsection{Antioxidant and drug detoxification genes}

In a study on 500 male cases of head and neck squamous cell carcinoma, cases with null genotypes of GSTM1 and GSTT1 or variant genotypes of GSTP1 had a significantly higher response to treatment (Ruwali M et al. 2011).

\subsubsection{Drug-metabolizing enzymes' genes}

In a study to assess the effect of CYP2D6 polymorphisms on the response to chemoradiotherapy in head and neck cancers, CYP2D6*4 and CYP2D6*10 polymorphisms result in poor response to treatment (Shukla P et al. 2012).

\subsection{Toxicity post chemoradiotherapy}

\subsubsection{DNA repair genes}

\subsubsection{Base excision repair pathway}

In a study, there was a significant association between XRCC1-399GIn allele and mucositis in patients with chemoradiotherapy (CRT). XRCC1-399GIn allele was not significantly associated with skin toxicity (erythema) (Pratesi et al. 2011).

In Nanda et al. study to explore the relation of XRCC-1 Arg194Trp polymorphism with toxicity in HNSCC patients achieving chemoradiotherapy, patients with polymorphic variant had more chance to experience severe acute toxicity including oral mucositis, dermatitis, and laryngeal toxicity in comparison with wild type variant (Nanda et al. 2018).

\subsubsection{Nucleotide excision repair pathway}

In Lopes-Aguiaret et al. study to explore the effect of nucleotide excision repair gene polymorphisms on toxicity of HNSCCs treated with cisplatin-based chemoradiotherapy, patients with XPC c.2815AA and XPD c.934AA genotypes had significantly more chance to experience moderate/ severe ototoxicity. Patients with XPD c.934 GG genotype had significantly more chance to experience moderate/ severe nausea. Patients with XPD c.2251 AC or CC genotypes and ACT haplotype of XPD and ERCC1 SNPs had significantly more chance to experience moderate/ severe nephrotoxicity (Lopes-Aguiar et al. 2017).

\subsubsection{Homologous recombination repair pathway}

In Pratesi et al. study, there was a significant association between RAD51 c.-3429 CC/GC genotypes and higher grade dysphagia in patients with chemoradiotherapy treatment (Pratesi et al. 2011).

\subsubsection{Mismatch repair pathway}

In Nogueira et al. study to investigate the effect of gene polymorphisms on toxicity in HNSCC patients treated with cisplatin based chemoradiotherapy, MSH3 GG and EX01 rs9350 CC genotypes were significantly associated with occurrence of 


\section{Impact of gene polymorphisms on toxicity and response to targeted therapy}

\section{1. response to targeted therapy \\ 4.1.1. Antibody-dependent cellular cytotoxicity (ADCC)}

In a study, HNSCC cell lines were susceptible to cetuximab induced ADCC (cetuximab is a monoclonal antibody targeting epidermal growth factor receptor [EGFR]). Efficacy of ADCC was associated with FcyRllla-158 polymorphism. ADCC was highest in Natural killer cells (NKs) with a single V allele (Taylor et al. 2009).

\subsubsection{Cell proliferation}

In a study to investigate the response of HNSCC cell lines to targeted therapy with cetuximab in relation to Aurora kinase A (AurkA) polymorphism, AurkA/STK15 Phe31lle polymorphism was associated with resistance to treatment. The Phe31 homozygous variant (Cal27 cells) were associated with decreased clonogenic survival (Pickhard et al. 2014).

\subsubsection{Growth control}

In a study to investigate cetuximab resistance in HNSCCs, cell lines with high K-allele frequency of EGFR-K ${ }_{521}$ polymorphism resisted against cetuximab and colony formation in these cell lines was not significantly affected; on the other hands, colony formation was inhibited while treating these cell lines with erlotinib (Braig et al. 2017).

5. Impact of gene polymorphisms on toxicity and response to combined targeted therapy and chemotherapy/radiotherapy

\subsection{Response to combined targeted therapy and chemotherapy/ radiotherapy}

\subsubsection{Cell proliferation}

In a study to assess the effect of PI3K/PTEN/AKT/mTOR polymorphisms on treatment response of recurrent or metastatic head and neck cancer patients treated with cetuximab-docetaxel, none of the studied polymorphisms had any significant association with treatment response (Pfisterer $\mathrm{K}$ et al. 2015).

In a study to evaluate treatment response of HNSCC cells to radiation in relation to Aurora-Kinase (AURK) polymorphism, their results showed that the Aurora-Kinase A Phe31-lle-polymorphism affects response to radiation in combination with Docetaxel and AURKA inhibitors (Baumann et al. 2018).

\subsection{Toxicity and response to combined targeted therapy and chemotherapy/ radiotherapy}

In a study to investigate the association of two genetic variations in the EGFR gene, EGFR-R521K and CA-SSR polymorphisms, with skin toxicities in patients with recurrent or metastatic HNSCC treated with cetuximab-docetaxel. EGFRR521K genotype $(G / G)$ had a significant association with sever dermatitis (skin rash). There was not any significant association between CA-SSR polymorphism and skin toxicity (Klinghammer et al. 2010).

In a study to investigate the effect of EGFR pathway polymorphisms on cetuximab toxicity in HNSCCs, there was a significant relationship between dry skin and total cetuximab toxicity with rs61764370 SNP of KRAS-LCS6 gene; patients 
with G allele had less dry skin. Patients with A allele for rs2227983 SNP of EGFR had less pruritus (Fernandez-Mateos et al. 2016).

\section{Discussion}

Fas ligand (FasL), as a mediator of apoptosis, upregulates in HNC cells treated with genotoxic agents such as cisplatin and 5-fluorouracil (5FU) (the main chemotherapy drugs used in HNSCC treatment). Matrix metalloproteinases (MMPs) may be involved in the process of carcinogenesis and resistance to treatment in different ways. MMP-3 is involved in the shedding of FasL from the cell surface which reduces the stimulation of Fas-mediated apoptosis and thus resistance to chemotherapy. In MMP3-1612insA polymorphism, Allele 6A is associated with low transcription rates; this down-regulation of MMP-3 can justify a better response to chemotherapy in patients with this polymorphism (Blons et al. 2004).

The cytotoxic effect of cisplatin is by forming adducts in DNA that results in cross-linking. One of the resistance mechanisms to cisplatin is a high potential of DNA repair. Polymorphisms in ERCC1 (C8092A), XPD (Asp312Asn and Lys751GIn) and XRCC1 (Arg399GIn) genes probably result in decreased DNA repair potential and accordingly lead to more sensitivity to cisplatin (Quintela-Fandino et al. 2006).

Parts of anti-cancer effect of radiotherapy and chemotherapy are possibly through production of reactive oxygen species (ROS); Glutathione s-transferase (GST) enzymes detoxified these products and are involved in protecting cells from cytotoxic agents and drugs (such as cisplatin). Heterozygous genotype of GSTP1 I105V polymorphism or null genotypes of GSTM1 or GSTT1 may result in lower or deficient activity of GSTPi enzymes and accordingly less effective or deficient capacity of detoxification. This will provide a better response to cisplatin or radiotherapy treatments and reduce drug resistance (Kimura et al. 2004, Ruwali et al. 2011).

Although the relation of $\operatorname{Arg}^{388}$ allele of FGFR4 Gly/Arg polymorphism with chemosensitivity was not significant but the resultant tendency toward increased chemosensitivity can be suggestive of its role in chemosensitivity because many other factors and genes such as P53 and $\mathrm{BCl}_{-\mathrm{XL}}$ may also affect drug sensitivity and such an increase is acceptable for one SNP (Ansell et al. 2009).

Cetuximab is a monoclonal antibody to epidermal growth factor receptor (EGFR) which main mechanism of action is through inhibition of EGFR. One of the lesser known mechanisms of cetuximab action is ADCC. Polymorphisms of Fc gamma receptor (FcyR) result in different binding affinity to lgG. FcyRIlla are present on effector cells like natural killer cells (NKs). FcyRIlla polymorphism on NKs is thought to affect ADCC, thereby showing a better tumor response to treatment (Taylor et al. 2009).

Radiotherapy, as a treatment for head and neck cancers, affects the normal tissues around the tumor and can cause acute (mucositis, dermatitis and dysphagia) and late complications (fibrosis). Patients' normal tissue responses are different even to similar doses of radiotherapy, and the radiotherapy dose should be adjusted accordingly. It has been hypothesized that the polymorphisms of DNA repair genes (like XRCCs) and genes related to protection against reactive oxygen species (like GSTs) are effective in variation of normal tissue reactions of different patients to radiotherapy (Alsbeih et al. 2008; Werbrouck et al. 2009; Pratesi et al. 2011).

CYP2D6 enzyme, as one of the cytochrome P450 (CYP450) enzymes, is very important in the metabolism of drugs. Polymorphisms of related gene result in variation of enzyme activity. These polymorphisms usually cause reduced or deficient activity of enzyme activity (Shukla et al. 2012).

Docetaxel chemotherapeutic drug functions through cell cycle arrest and apoptosis. Cetuximab (anti-EGFR antibody) acts through effect on cell survival and cell cycle progression. PI3K/PTEN/AKT/mTOR pathway is involved in the abovementioned processes. Although gene polymorphisms in this pathway have been reported to be involved in treatment response in esophageal cancer and non-small cell lung cancer, they had no association with treatment response in head and 
neck cancers. The reason for this difference could be related to the effect of other gene polymorphisms in head and neck cancers, which reduces the effect of gene polymorphisms of PI3K/PTEN/AKT/mTOR pathway in response to treatment of head and neck cancers (Pfisterer et al. 2015).

It was hypothesized that individual radiosensitivity is effective in occurrence of osteoradionecrosis (ORN) post radiotherapy. High frequency of reactive oxygen species (ROS) and oxidative stress after radiotherapy worsens tissue necrosis. Indeed the potential of each individual to combat oxidative stress affects unfavorable outcome such as ORN post radiotherapy. A proper biomarker for oxidative stress is 8-oxo-dG. It has been suggested that 8-oxo-dG levels can be regulated by SNPs in genes involved in oxidative stress response such as glutathione s-transferase (GST) (Danielsson et al. 2016).

EGFR is a transmembrane tyrosine kinase receptor that is involved in signaling pathways which have roles in DNA repair, cell survival (PI3K-PTEN-AKT pathway), and cell proliferation (RAS/RAF/MAPK pathway). It has been proposed that gene polymorphisms of each of downstream effectors of EGFR pathways can affect cetuximab (an anti-EGFR drug) toxicity (Fernandez-Mateos et al. 2016).

\section{Conclusion}

Studying the SNPs of genes involved in DNA repair, cell proliferation, growth control, apoptosis, response to oxidative stress, drug detoxification, connective tissue remodeling, drug-metabolizing enzymes can help us to move toward personalized medicine. By knowing each person's genetic characteristics and gene polymorphisms, it is possible to determine which therapy in that individual will have the best response or to avoid the use of treatments that may be associated with severe tissue toxicity.

\section{Declarations}

Ethics approval Not applicable.

Consent to participate Not applicable.

Consent for publication (include appropriate statements)

Conflict of interest The authors declare no competing interests.

Open Access This article is licensed under a Creative Commons Attribution 4.0 International License, which permits use, sharing, adaptation, distribution and reproduction in any medium or format, as long as you give appropriate credit to the original author(s) and the source, provide a link to the Creative Commons licence, and indicate if changes were made. The images or other third party material in this article are included in the article's Creative Commons licence, unless indicated otherwise in a credit line to the material. If material is not included in the article's Creative Commons licence and your intended use is not permitted by statutory regulation or exceeds the permitted use, you will need to obtain permission directly from the copyright holder. To view a copy of this licence, visit http://creativecommons.org/licenses/by/4.0/.

\section{References}

1. Alsbeih GA, et al. Association between XRCC1 G399A polymorphism and late complications to radiotherapy in Saudi head and neck cancer patients. J Egypt Natl Cancer Inst. 2008;20(3):302-8.

2. Ansell A, et al. Polymorphism of FGFR4 in cancer development and sensitivity to cisplatin and radiation in head and neck cancer. Oral Oncol. 2009;45(1):23-9.

3. Baumann A, et al. The Aurora-Kinase A Phe31-lle polymorphism as possible predictor of response to treatment in head and neck squamous cell carcinoma. Oncotarget. 2018;9(16):12769.

Page 13/15 
4. Blons $\mathrm{H}$, et al. Matrix metalloproteinase 3 polymorphism: a predictive factor of response to neoadjuvant chemotherapy in head and neck squamous cell carcinoma. Clinical Cancer Res. 2004;10(8):2594-9.

5. Braig $\mathrm{F}$, et al. Cetuximab resistance in head and neck cancer is mediated by EGFR-K ${ }_{521}$ polymorphism. Cancer Res. 2017;77(5):1188-99.

6. Danielsson D, et al. Influence of genetic background and oxidative stress response on risk of mandibular osteoradionecrosis after radiotherapy of head and neck cancer. Head Neck. 2016;38(3):387-93.

7. Fakhry $\mathrm{C}$, et al. Improved survival of patients with human papillomavirus-positive head and neck squamous cell carcinoma in a prospective clinical trial. J Natl Cancer Inst. 2008;100(4):261-9.

8. Farnebo L, et al. Proteins and single nucleotide polymorphisms involved in apoptosis, growth control, and DNA repair predict cisplatin sensitivity in head and neck cancer cell lines. Int J Mol Med. 2009;24(4):549-56.

9. Fernandez-Mateos J, et al. Epidermal growth factor receptor (EGFR) pathway polymorphisms as predictive markers of cetuximab toxicity in locally advanced head and neck squamous cell carcinoma (HNSCC) in a Spanish population. Oral Oncol. 2016;63:38-43.

10. Kimura S, et al. The relationship of the human glutathione S-transferase P1 polymorphism and chemotherapeutic sensitivity in head and neck squamous carcinoma. Int J Mol Med. 2004;14(2):185-9.

11. Klinghammer $\mathrm{K}$, et al. Association of epidermal growth factor receptor polymorphism, skin toxicity, and outcome in patients with squamous cell carcinoma of the head and neck receiving cetuximab-docetaxel treatment. Clin Cancer Res. 2010;16(1):304-10.

12. Lopes-Aguiar L, et al. XPD c. 934G> A polymorphism of nucleotide excision repair pathway in outcome of head and neck squamous cell carcinoma patients treated with cisplatin chemoradiation. Oncotarget. 2017;8(10):16190.

13. Nanda SS, et al. Evaluation of XRCC1 gene polymorphism as a biomarker in head and neck cancer patients undergoing chemoradiation therapy. Int J Radiat Oncol Biol Phys. 2018;101(3):593-601.

14. Nogueira GA, et al. Polymorphisms in DNA mismatch repair pathway genes predict toxicity and response to cisplatin chemoradiation in head and neck squamous cell carcinoma patients. Oncotarget. 2018;9(51):29538.

15. Pfisterer K, et al. PI3K/PTEN/AKT/mTOR polymorphisms: Association with clinical outcome in patients with head and neck squamous cell carcinoma receiving cetuximab-docetaxel. Head Neck. 2015;37(4):471-8.

16. Pickhard A, et al. The response of head and neck squamous cell carcinoma to cetuximab treatment depends on Aurora kinase A polymorphism. Oncotarget. 2014;5(14):5428.

17. Pratesi N, et al. Association between single nucleotide polymorphisms in the XRCC1 and RAD51 genes and clinical radiosensitivity in head and neck cancer. Radiother Oncol. 2011;99(3):356-61.

18. Quintela-Fandino M, et al. DNA-repair gene polymorphisms predict favorable clinical outcome among patients with advanced squamous cell carcinoma of the head and neck treated with cisplatin-based induction chemotherapy. J Clin Oncol. 2006;24(26):4333-9.

19. Ruwali $\mathrm{M}$, et al. Polymorphism in glutathione S-transferases: susceptibility and treatment outcome for head and neck cancer. Xenobiotica. 2011;41(12):1122-30.

20. Shukla P, et al. CYP 2D6 polymorphism: a predictor of susceptibility and response to chemoradiotherapy in head and neck cancer. J Cancer Res Ther. 2012;8(1):40.

21. Taylor RJ, et al. FcyRIlla polymorphisms and cetuximab induced cytotoxicity in squamous cell carcinoma of the head and neck. Cancer Immunol Immunother. 2009;58(7):997.

22. Tejasvi MA, et al. Impact of ERCC1 gene polymorphisms on response to cisplatin based therapy in oral squamous cell carcinoma (OSCC) patients. Indian J Pathol Microbiol. 2020;63(4):538.

23. Venkatesh $\mathrm{GH}$, et al. Polymorphisms in radio-responsive genes and its association with acute toxicity among head and neck cancer patients. PloS One. 2014;9(3):e89079. 
24. Wang C, et al (2020) Expression and genetic polymorphisms of ERCC1 in Chinese Han patients with oral squamous cell carcinoma. Biomed Res Int, 2020 (1): 1-6.

25. Werbrouck J, et al. Acute normal tissue reactions in head-and-neck cancer patients treated with IMRT: influence of dose and association with genetic polymorphisms in DNA DSB repair genes. Int J Radiat Oncol Biol Phys. 2009;73(4):118795.

26. Ziliak D, et al. Germline polymorphisms discovered via a cell-based, genome-wide approach predict platinum response in head and neck cancers. Transl Res. 2011;157(5):265-72. 